Firat Üniversitesi Sosyal Bilimler Dergisi

The Journal of International Social Sciences

Cilt: 27, Sayı: 2, Sayfa: 257-264, ELAZIĞ-2017

\title{
THE IMPACTS OF THE AGE FACTOR ON RELIGIOSITY
}

\author{
Yaş Faktörünün Dindarlık Üzerindeki Etkileri
}

\section{Murat SARI *}

\begin{abstract}
There is an important relationship between continuously fulfilling religious activities and age. Individuals involve religious activities more in their lives as they get older. Younger individuals feel more distant from death due to the feelings caused by their young age and chose to continuously fulfill their religious activities later. This study aims to examine the relationship between continuously fulfilling religious activities and age. In this context, the study evaluates whether or not individuals continuously fulfill their religious activities on the basis of the age factor. As a result of the study, it has been determined that advance age causes individuals to feel closer to death and consequently live a more religious life by continuously fulfilling religious activities.
\end{abstract}

Key Words: Religion, Religiosity, Age, Ageing, Death, Fear of Death

\section{ÖZET}

Dini faaliyetleri devamlı olarak yerine getirme ve yaş arasında önemli bir ilişki vardır. Bireyler, yaşları ilerledikçe hayatlarında dini faaliyetlere daha çok yer vermektedirler. Genç bireyler, yaşlarının vermiş olduğu duygularla kendilerini ölüme daha uzak hissetmekte ve dini faaliyetleri devamlı olarak yerine getirmeyi ileri yaşlardaki bir tarihe bırakmaktadırlar. Bu çalışma, insanların dini faaliyetleri sürekli yerine getirme ile yaş arasındaki ilişkiyi irdelemeyi hedeflemektedir. Bu çerçevede, bireylerin dini faaliyetlerini devamlı olarak yerine getirip, getirmemeleri yaş faktörü göz önünde bulundurularak değerlendirilmiştir. Çalışmanın sonunda, bireylerin yaşlarının ilerlemesinin kendilerini ölüme daha yakın hissetmelerine neden olduğuna ve bu durumunda bireyleri dini faaliyetleri sürekli yerine getirerek daha dindar bir şekilde yaşamaya sevk ettiği sonucuna ulaşılmıştır.

Anahtar Kelimeler: Din, Dindarlık, Yaş, Yaşlılık, Ölüm, Ölüm Korkusu

\section{Introduction}

The main question of this research is "Why young people seem to participate in religious activity far less than older generations in terms of doing daily prayers, go to mosque to pray and to read Qur'an daily." Age and attendance to religious activity is related to each other. Religion clearly plays a more important role in the lives of older people than in those of younger people. Firstly, many sociologists suggest that as older people see themselves becoming closer to death, they become more religious as they turn to religion as support and comfort. This view is supported by Malinowski's 'crisis of life' theory. Death is without a doubt a great change which is feared and so older people are more likely to turn to religion as a way of coping with their upcoming death. Younger people however are unlikely to feel particularly mortal or close to death and so the need for comfort and a coping mechanism received through religion is less. In a similar way, having children is likely to increase religious participation due to the wish to socialize children 'correctly'. Many see religion as providing a moral framework or guide with which to teach children morality. Therefore, as people get older and have children, their religious participation is likely to be higher than that of young people. In this view, these children, then socialized into religion, will likely return to it, if not remain in it as they age and have children of their own. A reason for the greater participation in religion by older people than younger people is the wish to rebel or break free from parents by young people. In a bid to assert their independence and individuality young people are likely to rebel against their parents and this means rebelling against the religion which they hold or a conscious choice to opt out of this belief when they reach adulthood. In addition, young people teenagers in particular - are more easily influence by their peers and the mass media which often

* Research Assistant, Firat University, Human And Social Science Faculty, ELAZIĞ muratsari@firat.edu.tr 
publicize cults and sects. This being a 'lack' in religious beliefs for young people is arguable in the attraction to cults and sects which young people often experience, coupled with the way in which many young people who join through rebellion or to find answers or security often leave the religious cults and sects as middle aged people. However, this is still a significantly lower number of young people than the number of older people who are religious.

Religion is one of the most important element of society in order to create social solidarity, social control and develop spiritual lifes of individuals. In this era, most of moral values and also religion damaged for many reasons. As a result of this, children, adolescences and young people avoid, pretend not to see org et rid of the existence of religion. It is dreadful because it's like a vicious cycle. When these young people become parent, they grow their children with lack of concept of religion, religious beliefs, morality and moral values. Then, this children will be grow and become adults which have families and they also have children who feel absence of these values. These concepts or facts are the elements which keep alive to society. And absence of these values very likely cause social and moral decadence. Because of that, this study has importance. This study is miniature of society which includes old people who are more religious and young generation who are far less than older people in terms of attendance to religious activities.

Allport and Ross (1967), who has conducted extensive research on religiosity, has described religiosity as "the practice of religion". According to Cornwall, Albrecht, Cunningham and Pitcher (1986), religiosity is a concept that encompasses the power and behavior of the individual's religious beliefs. McDaniel and Burnett (1990) define religiosity as "devotion to principles that are believed to have been regulated by God".

Religiosity can be understood as a fact that expresses a religious attitude, experience and style of behavior that is, religious life shown on the basis of faith-deed by humans living according to the commands and teachings of the believed religion. Religiosity has dimensions such as belief, practice, experience/emotion, knowledge, consequence/effect and organization (Okumuş, 2008). In the Islamic context, religiosity has the same definition. For religious Muslims, Islamic practices and worship are criteria for believers to be described as religious or devout. Of course, people can be characterized as more or less and strict or soft according to various levels of having "taqwa" (piety). There is more subjectivity in piety such prayer, fast, hajj so on. Okumuş (2008) defines the religiosity from several perspectives such as traditional religiosity and modern religiosity.

Young people seem to participate in religious activity far less than older generations in terms of performance of daily prayers, fasting and daily recitation of holy Qur'an. Firstly, many sociologists suggest that as older people see themselves becoming closer to death, they become more religious as they turn to religion as support and comfort (Nelson, 2009). Y1ldiz (2001) study on worry about death and age correlation. Young people - teenagers in particular - are more easily influence by their peers and the mass media which often publicize cults and sects. This being a 'lack' in religious beliefs for young people is arguable in the attraction to cults and sects which young people often experience, coupled with the way in which many young people who join through rebellion or to find answers or security often leave the religious cults and sects as middle aged people. However, this is still a significantly lower number of young people than the number of older people who are religious.

Schieman and Bierman (2007) examine the effects of the frequency of religious attendance and prayer on changes in the sense of divine control. In Johnson, Argue and White's (1999) analysis of Age and Religiosity, they mention to strong effect of age in participation of religious activities. They told about the fixed effects model and according to that model, religiosity increases with age. Cornwall (1989) told about age in her research "The Determinants of Religious Behavior: A Theoretical Model and Empirical Test "in order to explore demonstrated effect on religious beliefs and commitments.

A reason for the greater participation in religion by older people than younger people is the wish to rebel or break free from parents by young people. In a bid to assert their independence and 
individuality young people are likely to rebel against their parents and this means rebelling against the religion which they hold or a conscious choice to opt out of this belief when they reach adulthood. In the article of Saktanber (2007), - Cultural Dilemmas of Muslim Youth: Negotiating Muslim Identities and Being Young in Turkey - she explores, Muslim youth will contribute to the development of individual freedoms, tolerance, and mutual understanding. Also, new generations may tend towards new forms of religiosity distinct from that of their parents and religious authorities as well as from their earlier generations should not be disregarded. Thus, they are constantly open to producing new forms of cultural dilemmas.

Acar, Y1ldırım, and Ergene's work (1996), there is a table that show the sample of several age groups in terms of religiosity levels. According to this study, while people who are between the age of 16-18, are less interested with religion (\%58), this proportion is $\% 26$ for people whose age between 51-65. Arslan (2003) expressed to popular religiosity in the light of sociological variables such age, education, occupation, gender in his study: Development of Popular Religiosity Criterion: Validity and Reliability. Winchester (2008) researched how Muslims demonstrating the practices of prayer, fasting, and so on. Age influences religious behaviors and activities. Death is without a doubt a great change which is feared and so older people are more likely to turn to religion as a way of coping with their upcoming death. Younger people however are unlikely to feel particularly mortal or close to death and so the need for comfort and a coping mechanism received through religion is less.

There is a study that similar which done by Stephen C. Ainlay, Royce Singleton and Victoria L. Swigert (1992). This study examined the relationship between aging and religious participation, focusing on changes in order people's formal participation in church life, informal or private religious practices and attitudes towards participation in the church.

\section{Research Methods}

For this study, variables are age (independent variable) and participation to religious activities (dependent variable). Age is the concept that known as the time that a person or a thing has existed since birth or beginning. We can divide the age to five categories such; Chronological age (calendar age), Functional age (related to physical health, cognitive abilities), Psychosocial age (related to self-perception, social perception), Organizational age (related to social perception, company tenure, career stage, skill obsolescence) and Life-span age (related to life stage / family status). (http://www.tilburguniversity.n1/faculties/fsw/departments/HRS/SGM/presenation/Kooij. ppt) Religious activity is the set of individual and communal practices that they perform to develop and express their spiritual nature. I examined to doing daily prayers, go to mosque to pray and to read Qur'an daily as religious activities in this study. Age is important determinant which effects to attendance to religious activities. I tried to prove young generations participate to religious activities such doing daily prayers, reading to Qur'an daily, to go to mosque to pray (Friday prayer) less than old generations.

\section{Sample}

The participants in this study were 120 people (\%67 females, $\% 53$ males). In this study the 120 people are volunteers who want to participate in the study. Random sampling technique is used in this study. The age range of this sample was under 30,30 s to $45 \mathrm{~s}$ and above $45 \mathrm{~s}$. The survey area is "Avcllar-Marmara Caddesi ". I prefer this area because there are two mosque at the top and end of Marmara Caddesi. There are some fast food restaurants, cafes, bars, cloth stores in Marmara Caddesi. So, Avcilar, also this street, includes both young and old generation. I think I can prove my survey question- namely, young generation who spend time in cafes, fast-food restaurants, stores so on, and old generations who go to mosque to pray, and the differences between them in terms of participation to religious activity. This study was carried out between 22.08.2016/ 05.09.2016. I choose the time as 12:00 - 19:00. Because at these times, students left from their schools or training centers and also these times are prayer times both noon time and mid-afternoon prayer times. I think Avcılar- Marmara Caddesi is suitable for my study. Because it includes both 


\section{F.Ü. Sosyal Bilimler Dergisi 2017-27/2}

old and young people, students, conservatives and seculars. Marmara Caddesi like a mosaic which have people from every ideology, lifestyle, beliefs and thoughts.

\section{Measure}

I use survey method in this project. A single item asked: "Imagine that you died and you now find yourself standing before God. He asks you, "Why should I let you into my heaven?" What would you say? "Response choices are: "Because I have been a good person." (1), "Because I have earned the right to go to heaven."(2), "Because I have obey/ apply all Islamic rules."(3), "Because I believe that God has the power to forgive sins." (4) and "I would be speechless".

Frequency of attendance to religious ceremonies \& services. A single item asked: "How often do you attend religious ceremonies and services such pray with congregation, to participate certain occasions/ religious ceremonies/conversations? ". Response choices are: " Daily "(1), "Weekly "(2), "Several times a year " (3), "Annually" (4), " Rarely " (5) and "Never "(6).

Frequency of prayer. The question was: "How many times did you pray last week?". Response choices are: "Daily" (1), "Several times in a week"(2), "Few times in a week "(3) and "Never" (4).

Frequency of reading Quran. A single question asked: "Outside of attending religious services, how often do you read the Qur'an?". Response choices are : "Daily"(1), "Weekly " (2), "Several times a year " (3), "Only on certain occasions "(4), "Once or twice a year " (5) and "Never"(6).

A single item ask respondents about the level of agreement or disagreement with this statement: "I believe attending to religious ceremonies and services is develops my spiritual life". Response choices are : "Strongly Agree " (1), "Agree " (2), "Unsure " (3), "Disagree " (4) and "Strongly Disagree " (5).

Age I coded the ages which under 30 as " 1 ", 30 s to 45 s as " 2 " and above 45 s as " 3 ".

The data of the study is analyzed with the Spss 16 program. The value of the data is interpreted with chi-square. When p-value is less than 0.05 in chi-square, variables are the significantly related with each other.

Graph 1: How Often Do You Read The Qur'an?

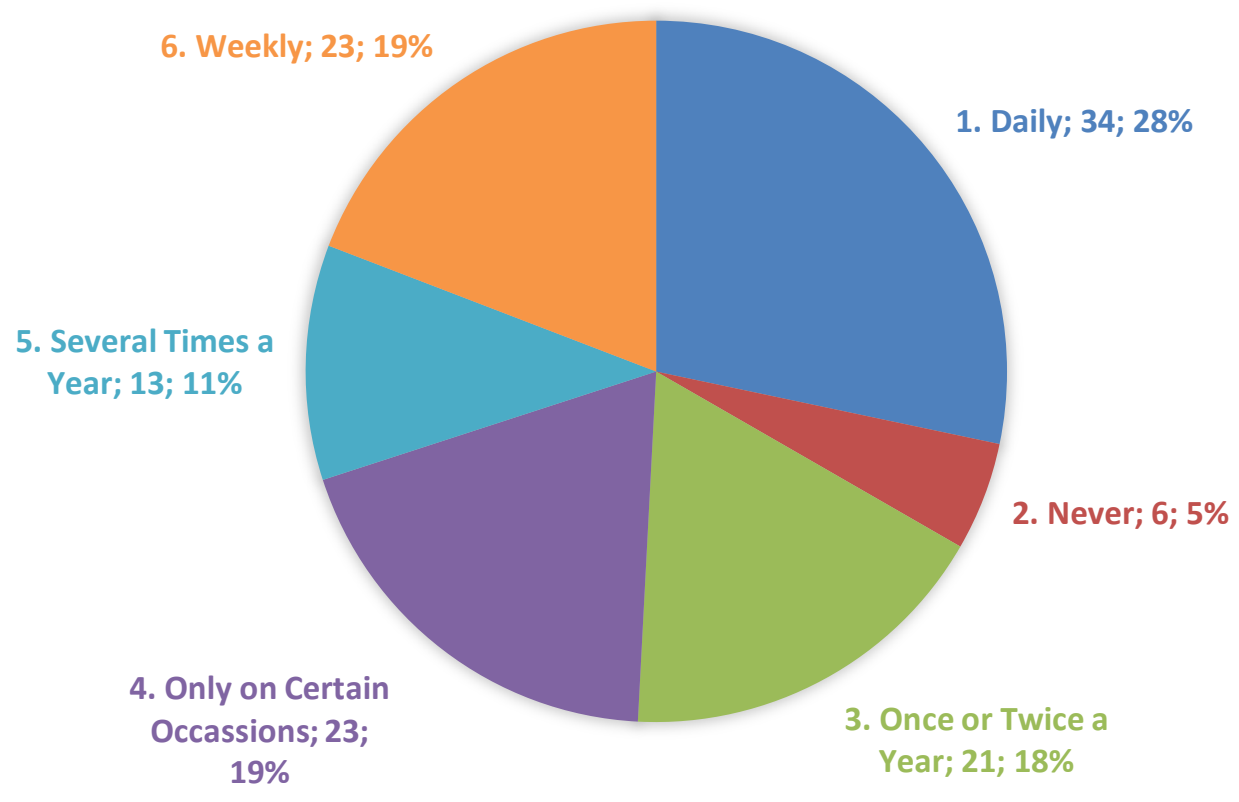


6 people whose age under 30 never read Qur'an, 34 people who read Qur'an daily are at the age of above 45+. Advanced age causes individuals to grow mature and think more profoundly. Individuals who reach a certain advanced age begin considering death and afterdeath more frequently. Because advanced age causes them to feel closer to death. As is seen in the table, the daily religious activity of reading the Qur'an is performed by individuals older than 45 . Some of the individuals younger than 30 stated that they did not even know how to read the Quran let alone reading it in certain times, which, to some extent, shows us how much attention young individuals pay to religious activities.

Graph 2: How Many Times Did You Pray Last Week?

4. Few Times in a

Week; 3; 2\%

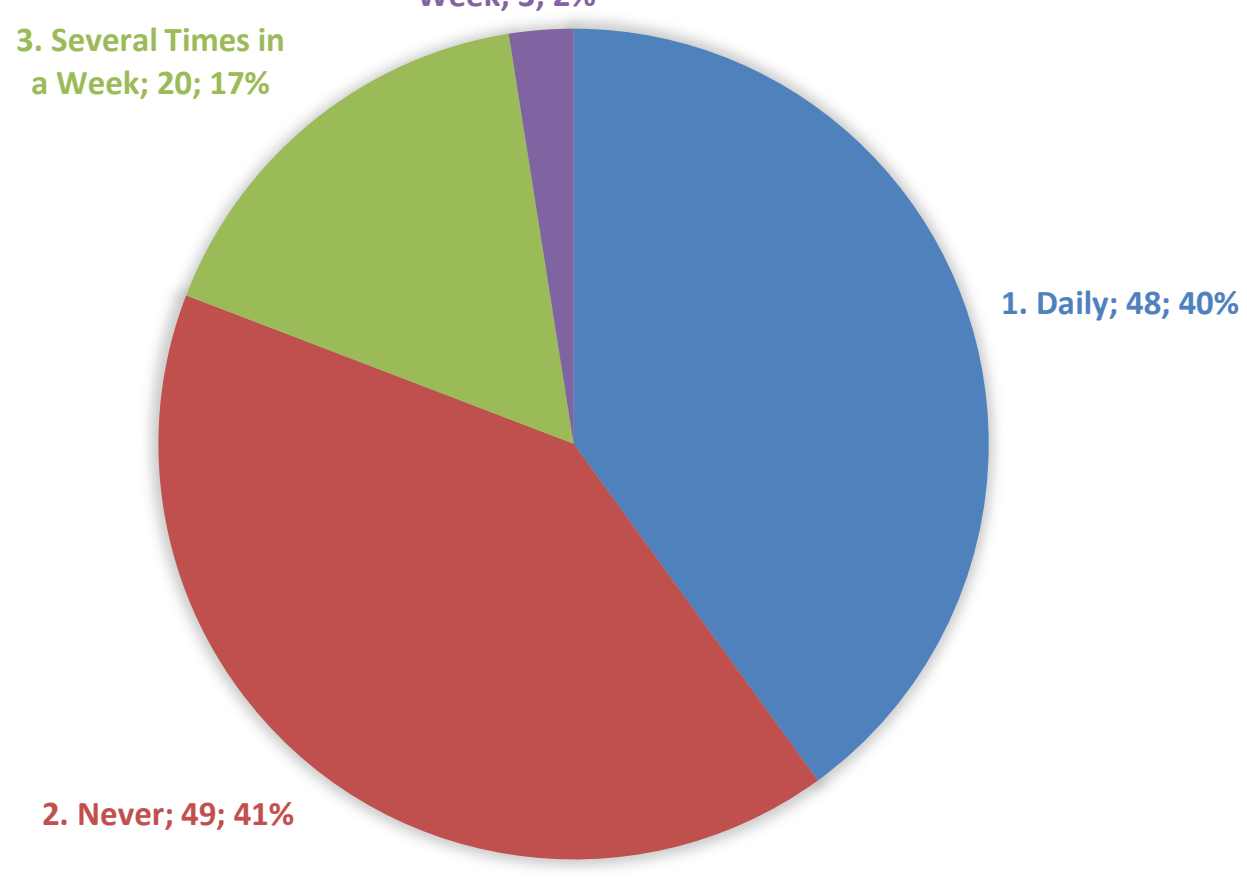

48 people pray daily in a week, 23 people are at the age of above $45+$ and 11 people are under the age of 30. Also 49 people never pray in a week and 40 of them are at the age of under 30 . According to Islam, "Salaat is the basis of religion", which underlines the importance of salaat among religious activities. In other words, religious sensibility is based on performing the salaat regularly. We may guess the religious sensibility of people by considering their frequency of performing the salaat. Considering the data in the table; it is seen that majority of individuals who never perform the salaat consist of the youth, which proves the weakness of religious sensibility in the youth. As young individuals do not feel close to death, they do not regard performing the salaat so much. They state they they have time and will regularly perform the salaat in the future. 
Graph 3: How Often Do You Pray Outside Of Religious Services?

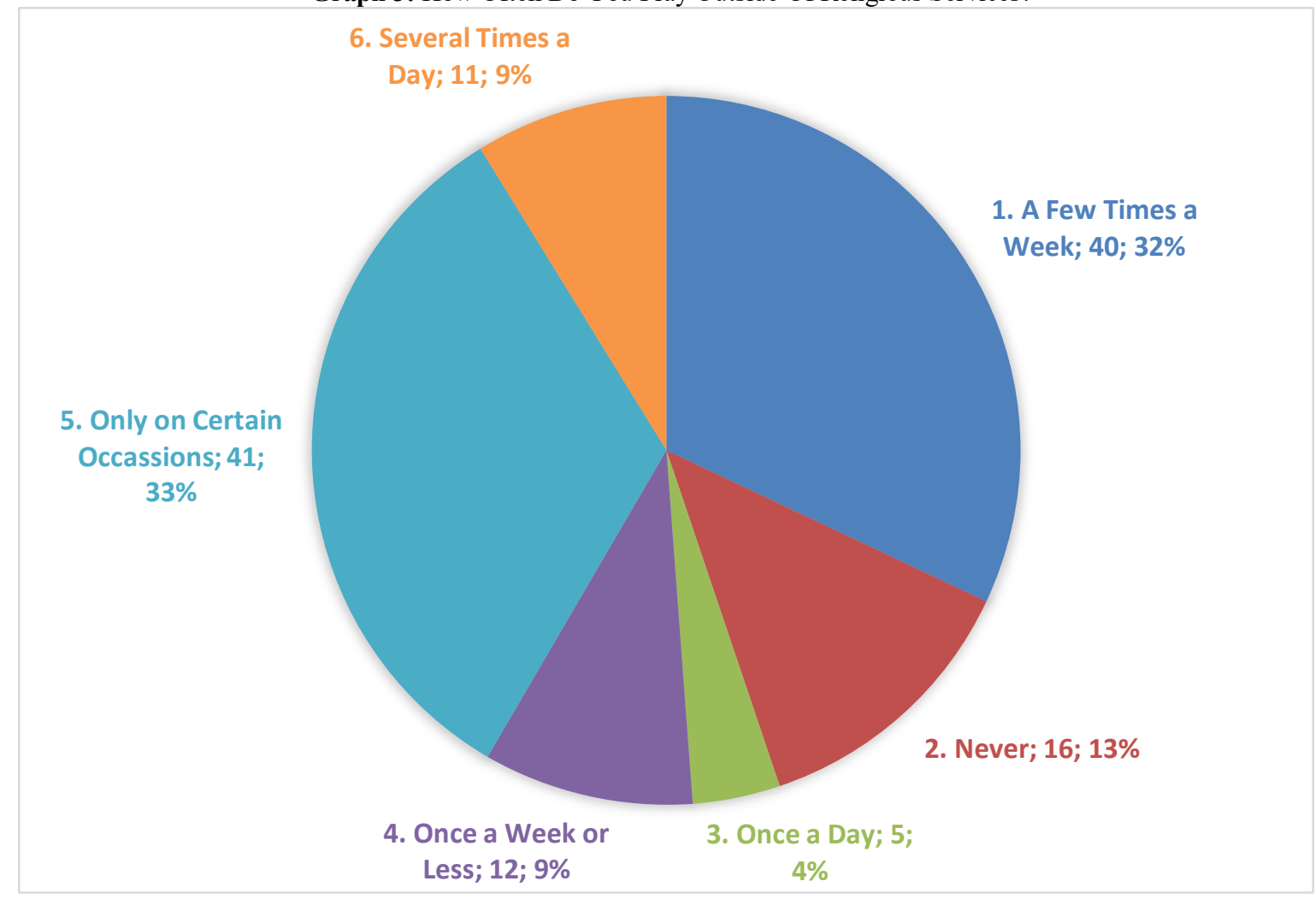

41 people pray out of religious services only on certain occasions and 28 of them are under the age of 30s. 11 people pray out of religious services and 7 of them above $45+$ ages. 16 people never pray out of religious services and 15 of them are under age of 30 . There is an important relationship between the phenomenon of age and fulfillment of religious activities and religious devotion. People do not show much sensibility towards religion and religious activities when they are young. Because it is more appealing especially for young individuals to spend their time on other activities than religious activities. Older individuals, on the other hand, do the total opposite. They spend more time on religious activities as they think that doing earthly things is only a waste of time. According to the data acquired from the table; older individuals pay a greater attention to praying, which is among religious activities, and they frequently pray as a life habit.

Table 1: Status of respondents on praying in a week

Recoded Age * Recoded Pray Last Week Crosstabulation

\begin{tabular}{|l|c|c|c|c|}
\hline Recoded Age & Daily & $\begin{array}{c}\text { Several Times In A } \\
\text { Week }\end{array}$ & $\begin{array}{c}\text { Few Times In A } \\
\text { Week }\end{array}$ & Total \\
\hline Under 30 Age & 19 & 4 & 40 & 63 \\
\hline 30-45 Age & 16 & 2 & 5 & 23 \\
\hline 45+ Age & 29 & 2 & 4 & 35 \\
\hline Total & 67 & 8 & 49 & 124 \\
\hline
\end{tabular}

To interpret chi-square; chi-square: 31,014 with df:4, $p$ value: 0,0301 . Chi-square is less than the 0,05 . Therefore variables are related. So, pray in a week is related to age. As is seen in the table above, individuals younger than 30 have lower rates of performing the salaat, which is among daily religious services. Because individuals who are younger than 30 and are considered young feel distant to death and thus, they do not regard performing the salaat so much. On the other hand, considering the table, it is seen that individuals older than 45 pay strict attention to regularly performing the salaat everyday. Because individuals older than 45 feel closer to death due to both their life experiences and advanced age. It is observed that individuals who feel closer to death pay 
sufficient attention to performing the salaat, which is among religious activities aimed at preparing to afterdeath, and try to regularly perform the salaat everyday.

Table 2: Frequency Of Reading Qur'an

Recoded Age * Recoded Read Quran Crosstabulation

\begin{tabular}{|l|c|c|c|c|c|}
\hline Recoded Age & Daily & Weekly & $\begin{array}{c}\text { Several Times a } \\
\text { Year }\end{array}$ & Never & Total \\
\hline Under 30 Age & 22 & 20 & 5 & 16 & 63 \\
\hline 30-45 Age & 13 & 5 & 1 & 4 & 23 \\
\hline 45+ Age & 22 & 11 & 0 & 1 & 34 \\
\hline Total & 57 & 36 & 6 & 21 & 120 \\
\hline
\end{tabular}

Calculated chi-squared $=14,431$ with $d f=6 p=0.0251$. Chi-square is less than the 0,05 . Therefore variables are related. So, frequency of reading Qur'an is dependent to age. And again we can see the validity of my research question: young people are less participate to religious activities such as reading Qur'an, we see from table 16 people whose age under 30 never read Qur'an, while 1 person whose age above 45+ never read Qur'an. Considering the table above in general; individuals older than 30 perform the religious activity of reading the Quran more frequently. The youth who are younger than 30 have a lower frequency of reading the Quran. According to the acquired data; age factor also affects the religious activity of reading the Quran. The fact that death is an inevitable ending and advanced age causes individuals to feel closer to death leads to religiousness.

Table 3: Attendance To Religious Ceremony \& Services

Recoded Age * Recoded Attendance To Religious Ceremony Crosstabulation

\begin{tabular}{|l|c|c|c|c|c|c|c|}
\hline Recoded Age & Daily & Weekly & $\begin{array}{c}\text { Several } \\
\text { Times a } \\
\text { Year }\end{array}$ & Annualy & Rarely & Never & Total \\
\hline Under 30 Age & 2 & 8 & 9 & 1 & 28 & 15 & 63 \\
\hline 30-45 Age & 2 & 7 & 4 & 0 & 9 & 1 & 23 \\
\hline 45+ Age & 7 & 15 & 7 & 1 & 4 & 0 & 34 \\
\hline Total & 11 & 30 & 20 & 2 & 41 & 16 & 120 \\
\hline
\end{tabular}

To interpret chi-squared $=35,839$ with $d f=10 \mathrm{p}=0.000$. Chi-square is less than the 0,05 . Therefore age is related to attending religious ceremony. 28 people rarely attend, 9 people attend several times a year and just 2 people whose age under 30 attend to religious services daily. Young individuals do not desire to participate in religious ceremonies and services unless they are obliged to. According to the acquired data; it is seen that individuals older than 30 pay a greater attention to daily and weekly religious services. Age is an important factor that affects the participation in and sustainment of religious activities. As advanced age allows individuals to have a certain life satisfaction, older individuals tend towards religion and pay a greater attention to religious services.

\section{Conclusion}

As a result of that survey and study, the research question "Why young people seem to participate in religious activity far less than older generations in terms of doing daily prayers, go to mosque to pray and to read Quran daily." is proved. Total of data's that I gathered show us, young generation are less participate to religious activities in compare to old generations. To talk and explain the questions were not easy things. Because religion is sensitive subject and people abstain to participate the survey. General scene of young people is that they are so relax and Younger people however are unlikely to feel particularly mortal or close to death. They easily choose "Never" as a choice.

Most of young people are not pray daily prayer, read Qur'an, attend to religious services and so on. On the other hand, old generation spend much more time with religious activities. They generally practice daily prayer, read Qur'an frequently. Because I think they feel themselves close 


\section{F.Ü. Sosyal Bilimler Dergisi 2017-27/2}

to death and in order to be comfortable they become more religious and so they supply support for their after-life.

In conclusion, the fact of religion continues to exert influence over the individual at all ages. As people age older, their sensitivity to performing religious activities is also increasing. Because people who are advancing age see themselves at the end of their life. Individuals who think they have consumed their lives tend to be more religious in order to be prepared for life after death. But this condition is very different on young people. Young people do not want to think about death. They feel death away from them and do not care much about participating in religious activities.

\section{References}

Acar, Nilüfer Voltan, İbrahim Yıldırım, and Tuncay Ergene. 1996. "Bireylerin Dindarlık Düzeylerinin Bazı Değişkenler Açısından İncelenmesi." [Investigation of Religiosity Level According to Several Variables] Hacettepe Üniversitesi Eğitim Fakültesi Dergisi [ Journal of University Of Hacettepe] 12(45).

Allport, G. W. \& Ross, J. M. (1967). Personal religious orientation and prejudice. Journal of Personality and Social Psychology, 5, 447- 457.

Arslan, Mustafa. 2003. "Popüler Dindarlık Ölçeğinin Geliştirilmesi: Geçerlik ve Güvenirlik Çalışması ." [Development of Popular Religiosity Criterion] Dinbilimleri Akademik Araştırma Dergisi [Academic Journal of Theology] 3(1). Retrieved February 2, 2016 (http://www.psikolojievi.com/pdf/59.pdf ).

Bierman, Alex and Scott Schieman. 2007. "Religious Activities and Changes in the Sense of Divine Control: Dimensions of Social Stratification as Contingencies." Sociology of Religion 68(4): 361-381.

Cornwall, M., Albrecht, S.L., Cunningham, B.H. \& Pitcher, B.L. (1986). The dimensions of religiosity: A conceptual model with an empirical test", Review of Religious Research, 27(3), 226- 243.

Cornwall, Marie. 1989. “The Determinants of Religious Behavior: A Theoretical Model and Empirical Test. “ Social Forces 68(2): 572-592.

Johnson, David R., Lynn K. White, and Amy Argue. 1999. “Age and Religiosity: Evidence from a Three-Wave Panel Analysis."Journal for the Scientific Study of Religion 38(3): 428-435.

McDaniel, S.W. \& Burnett, J.J. (1990). Consumer religiosity and retail store evaluative criteria. Journal of the Academy of Marketing Science, 18(2), 101- 112. 433.

Nelson, James M.. 2009. "Practices and Religious Communities.“ Psychology, Religion, and Spirituality. Pp 391-

Okumuş, Ejder. 2008. “Turkey-Religiosity and the PRA .” Muslim World 98(2/3): 345-362.

Saktanber, Ayşe. 2007. "Cultural Dilemmas of Muslim Youth: Negotiating Muslim Identities and Being Young in Turkey." Turkish Studies 8(3): 417-434.

Singleton Jr., Royce, Victoria L. Swigert, and Stephen C. Ainley. 1992. "Aging and Religious Participation: Reconsidering Effects of Health.“ Journal for the Scientific Study of Religion 31(2): 176-188.

Winchester, Daniel. 2008. "Embodying the Faith: Religious Practice and the Making of a Muslim Moral Habitus “ Social Forces 86(4): 1753-1780.

Yıldız, Murat. 2001. "Dindarlık ve Ölüm Kaygıs1.“ Journal of Religious Culture 43 (1): 1-7.

http://www.tilburguniversity.nl/faculties/fsw/departments/HRS/SGM/presenation/Kooij.ppt (23.12.2016). 